\title{
LOCAL WISDOM AND NATURAL DISASTER IN WEST SUMATRA
}

\author{
Syafwan Rozi \\ Jurusan Filsafat Agama FUAD IAIN Bukittinggi \\ Email: sya_ra_de@yahoo.co.id
}

Abstract:

Community-based disaster management is an attempt to optimize the potential of social and local values in communities to facilitate the handling of natural disasters. West Sumatra as one of the disaster-prone areas in Indonesia has a number of local wisdom values - a value combining religion and local culture - rooted in traditional philosophy; "Adat Basandi Syara', Syara' Basandi Kitabullah". The examples of those local wisdoms are customary ideas or proverbs in the form of legend and expressions, architectural design of the traditional house - "Rumah Gadang"- and the structure of the environment as well as the social systems of kinship and traditional administration in the form of Nagari. This research employed qualitative method by using ethnography approach. The data were collected through observations, participation in social events, and in-depth interviews. Those techniques were applied to obtain the valid information and the meaning of events and behaviors comprehensively. The local values applied by the indigenous communities as the victims of natural disasters in some regions of West Sumatra include "Badoncek" tradition in Nagari Tandikat Padang Pariaman, the architecture of "Rumah Gadang" in Nagari Sungayang, Tanah Datar and disaster mitigation based on district in Nagari Kubang Putiah Agam.

Managemen bencana berbasis masyarakat merupakan upaya untuk mengoptimalkan potensi sosial dan nilai-nilai lokal yang dimiliki masyarakat untuk memudahkan proses penanganan bencana alam. Sumatera Barat sebagai salah satu daerah rawan bencana di Indonesia, memiliki sejumlah nilai kearifan lokal, sebuah nilai yang memadukan antara agama dan budaya lokal yang termaktub dalam filosofi 
adat; Adat Basandi Syara', Syara' Basandi Kitabullah. Di antara kearifan lokal itu adalah ide atau pepatah adat dalam bentuk tambo dan ungkapanungkapan, tata ruang rumah adat dari segi arsitektur rumah gadang dan penataan lingkungannya serta sistem sosial kekerabatan dan pemerintahan adat dalam bentuk nagari. Penelitian ini menggunakan metode kualitatif dengan pendekatan etnografi. Pengumpulan data dilakukan melalui observasi, keterlibatan dalam kegiatan masyarakat dan wawancara mendalam. Teknik-teknik ini dilakukan untuk mendapat informasi yang valid dan mendalam serta menghayati makna atau arti peristiwa dan tingkah laku secara komprehensif. Adapun nilai-nilai kearifan lokal yang diterapkan komunitas adat di Sumatera Barat meliputi tradisi badoncek di Nagari Tandikat Padang Pariaman, arsitektur dan tata kelola rumah gadang di Nagari Sungayang Tanah Datar serta mitigasi bencana berbasis nagari di Nagari Kubang Putiah Kabupaten Agam.

Keywords: local wisdom; natural disaster; community disaster management

\section{Introduction}

West Sumatra is one of the disaster-prone areas in Indonesia. The amount of disaster potential in this region causes its own people name their region as "disaster department store". Based on historical records, West Sumatra had experienced the destructive earthquake for several times. From 1822 to 2016 there have been at least 17 times of powerful and destructive earthquakes in West Sumatra and some of which cause tsunami. The long history of destructive earthquake in West Sumatra includes the earthquake in Padang (1822, 1835, 1981, 1991, 2005, and 2009), the earthquake in Singkarak (1943), the earthquake in Pasaman (1977), the earthquake in Agam (2003) and the earthquakes in Tanah Datar (2007). While the earthquake followed by a tsunami occurred in the Mentawai $(1861,2010)$ and Sori-Sori (1904) (Danhas, 2011).

From geographical, geological, hydrological, and demographic perspective, West Sumatra is a region located in the volcanic path (ring of fire) which is at risk of volcanic eruptions. Besides, this area has 31 mountains which are located on top of active earth's crust where the five faults of tectonic plates meet and collide, known as watermelon fault. The fracture of the earth slab and crust have resulted a very dynamic movement. Accordingly, it is not surprising if the frequency of natural disasters in this area is quite high and they occur one after another starting from the earthquake, tsunami, floods, landslides, forest fires, and volcanoes (Sunarti, 2009). 
The management of several natural disasters in West Sumatra has been made by the local government to implement constitution number 24 in 2007 about disaster management. This regulation emphasizes that the implementation of disaster management includes a series of efforts such as the establishment of development policies on the risk of disaster, disaster prevention, emergency response and rehabilitation. In addition, the Government of West Sumatra province has had a legal bases related to disaster management, namely Decree of the Governor of West Sumatra number 32 in 2002 about the Standard Operational Procedure of Disaster and Refugees Management and the Regional Regulation of West Sumatra Province number 5 in 2007 about Disaster Management. Those laws and regulations are then followed up by each district/ city in West Sumatra. For example, Padang Pariaman Regency issued Regent Decree 112/Kep/BP/2007 about Executing Unit for Disaster Management (Satlak BP). While Bukittinggi municipal government has been more responsive by issuing a decree in 2005 about Executing Unit for Disaster Management and Standard Operational Procedure of PBP Bukittinggi (BPPT Team, 2010).

Therefore with the regulations and policies on disaster mitigation, the Government of West Sumatra received an award from the central government for its success in reducing the number of victims in the earthquake occurred on March, 6 and September, 12 to 13, 2009. The massive earthquake that struck West Sumatra and Bengkulu in September 2007 caused 25 people died. The number of casualties is relatively small when compared to victims of the earthquake occurred in Central Java and Yogyakarta, which reached more than 5000 people (Sunarti, 2009).

Nevertheless, some studies reveal and evaluate the disaster management in West Sumatra such as the studies conducted by Sunarti (2009), Danhas (2011), Suryati (2013), Rahman (2013), and Pradipta (2015). In general, these studies highlight the lack of disaster management strategy that ignores the potential resource and local capacity or even, in some cases, increases the vulnerability of local communities against disaster risks. Even though there is a model of community-based disaster management, but it is not well-organized to prevent, reduce, avoid, and recover the communities from the impact of disasters.

The issue above is considered very precarious. Nonetheless, this area has strong social systems and local wisdom values rooted in traditional philosophy; "adat basandi syara', syara' basandi kitabullah" which means that tradition is based on religion, and religion is based on Qur'an. It becomes a value and spirit to 
face the life or even disaster. In terms of local wisdom values, Minangkabau people have noble teachings based on Islamic teachings which are called as "berkulindan" in Minangkabau tradition. Those teachings include togetherness among the members of community gathered in the tribe, surroundings, ellipse, and villages as a social network as well as social leadership which is built under the foundation of trust, togetherness and loyalty, social responsibility, self-reliance and participation to face the natural disasters.

Therefore, community-based disaster management by strengthening religion and customs values incorporated in the local wisdom of Minangkabau society is a necessity because through optimizing the social potential and local wisdom which they have, it will ease the handling of disaster. The effort is a development model of the community-based disaster management that is now frequently conducted by government and non-governmental organization.

This research was conducted in the area of natural disaster in West Sumatra. The villages are Tandikat in Patamuan District, Padang Pariaman Regency which is the worst areas of earthquake in September 2009, Sungayang village, Tanah Datar Regency as traditional village and victim of the earthquake in 2007, and Kubang Putiah in Agam District, the nearest village to Mount Merapi. These villages are selected as the location of the research, because these villages are claimed as disaster-prone areas which caused the instability of social elements. Besides, these areas have experienced natural disasters and local wisdom values as an effort of handling natural disasters had been applied there.

\section{The History of Disaster in West Sumatra and the Handling: Flashback of Disasters Since 2005}

The glory of natural disaster management in West Sumatra started since the earthquake struck the capital of the province in 2005. Since that western region of Sumatra Island continues to be plagued by natural disasters, until the earthquake followed by a tsunami struck Mentawai Islands in 2010. In 2005 the city of Padang suffered an earthquake of 5.5 SR. For 4 months this city continues to experience aftershocks fewer than 4 SR. 4 magnitude earthquakes due to the eruption of Mount Talang in Solok occurred on April 2006. Since then the social mobility and rate in the city of Padang decreased because of the destruction of public facilities (Ismail, 2010).

Then, on March 6, 2007 tectonic earthquake rocked West Sumatra as a result of Tandikat slab movements with about 6.3 magnitudes that destroyed 
45,000 homes and killed 70 people. The earthquake which centered in Tanah Datar was then known as 2007 Tanah Datar earthquake. According to the BMG office in Padang Panjang on the second day after the earthquake, the number of earthquakes which have been recorded reaches 226 times. Those earthquakes have also triggered the seismic activity of Mount Talang in Solok and the formation of a new canyon in Gunung Rajo village in Tanah Datar. Padang-Bukittinggi and Padang-Solok Highway got stalled because of landslides (Erwin, 2011).

Furthermore, flash floods in Jorong Sasai kandang (Saskan) Malalak Agam occurred on Friday, November 10, 2008 increase the variety of natural disasters that hit the area. Four people were dead; two people were missing; 250 residents were evacuated; a number of houses, bridges and areas of paddy fields were damaged and destroyed; and material losses were about hundreds of millions rupiah (Padang Ekspress, 2008).

Eventually, the massive earthquake struck parts of West Sumatra in September 2009, known as G 30 S 2009. The city of Padang and Padang Pariaman is the region that suffered the worst by the 7.9-magnitude earthquake. Padang city and Padang Pariaman District are the two regions most affected and devastated by the earthquake. According to the Post, PBPD reports that the total death victims are 46 people, hundreds injured and thousands of buildings, roads and bridges destroyed by the earthquake (Padang Ekspress, 2009).

The disaster handling management of several natural disasters in West Sumatra has been made by the government and non-governmental organization. For instance, since the 2005 earthquake and tsunami lingering issues in Padang, the Provincial Government provides supporting device to detect tsunami in the form of Indonesian Tsunami Early Warning System or siren Ina TEWS which the range only in radius of $2 \mathrm{~km}$.

In addition, the simulation to overcome and avoid the dangers of tsunami is also done by the municipal government of Padang. Some people even formed a Tsunami Alert Community (KOGAMI) since July 2005. Unfortunately, according to the director of Kogami only 10 percent of the 600 thousand citizens have been trained for tsunami evacuation. In line with the statement above, the Chairman of the Association of Geologists Commissariat of West Sumatra as the Head of Disaster Alertness Division in West Sumatra Government, said that this simulation is only ceremonial,

el Harakah Jurnal Budaya Islam Vol. 19 No.1 Tahun 2017 
much more important is that the Government of Padang must make roads, evacuation routes, signs and refuge soon (Tempo Magazine, 2007).

Not only that, the support of the central government prioritize disaster relief operations (Pusdalops $\mathrm{PB}$ ) in this area even a number of overseas aid is directed to West Sumatra. The readiness of the society and government of Padang for a potential tsunami earthquake is not half-hearted. It is proven by the realization of the program of disaster preparedness, a program of socialization and simulated emergency response. In this program, the government cooperates with Japan Institution, LIPI, BPPT, PMI, UNAND, UNP, ITB and Telkom. So far, this program aims at training people in a tsunami simulation, zoning the areas that are safe from the tsunami, and making the standby map. In addition, the military, through Integration Exercise of Ureda Taruna Nusantara (Latsitardanus), recently construct two segments along the evacuation route along 1,300 meters and tsunami evacuation shelter or a place that holds 10,000 people (Singgalang, 2008).

The only problem is how the handling of natural disasters in the field. A research conducted by Effendi (2007) shows that especially for the tsunami earthquake emergency response program, government have formed the earthquake and tsunami post that is directly under the command of the Mayor of Padang city, which provides special telephone lines services, but unfortunately the phone number is active at the time of program in 2006, but in 2007 and 2009 until now the number is no longer active.

If we observe some of the disasters that have occurred, the disaster management system is still responsive. This is consistent with the statement of one of the Members of West Sumatra Parliament, Taslim, loaded by one of the daily newspaper in the form of an interview. According to Taslim, disaster management in this area is still responsive. The Steps are made at the time the disaster occurred. Peoples and governments are not prepared for the disaster. Culture and government policies are not oriented to the safety of humans and the environment as explained in the construction planning (Padang Ekspress, 2007).

The same thing also is expressed by Ir. Djonimar Boer recently along with Malalak flash flood that even early warning in the form of warning signs in disaster-prone areas with reference to the geological map has not been realized. According to Djon, the location in Malalak recently is the same location has suffered three similar disasters. But after the events passed, because it is not given hazard warning signs, residents re-build houses and inhabit the prone 
area (Singgalang, 2008). In fact, during West Sumatra earthquake in 2007, everyone seemed to forget that a very strong earthquake rocked, damaged and happened to the same houses in the earthquake-prone area in Gunung Rajo. Besides, as if Tui Hill landslide in 1987 that killed 114 people had been forgotten, in this high risk area, houses were re-established because warning signs of disaster areas is already gone (Resque Team, 2007).

In addition, various research findings also show how inter-relationships between the stakeholders with other elements are very weak. Setting policies or regulations of the technical level implemented by the parties are proved to be very helpful in disaster management. Good governance is increasingly confirmed by real commitment of local leaders who directly monitor and control each process and phases of disaster management in the region (Erwin, 2011).

Thus, the implementation of disaster management requires systematic coordination and must consider local culture and empower victims. One naive step is the application of disaster management systems by the central government that is not entirely suitable to be applied in West Sumatra, because the people in West Sumatra has a value system that is not equal to the values of the culture of other regions. According to Sunarti (2009), there are typical local values applied in this area. For example in the construction of homes affected by earthquake, if in Java (Central Java and Yogyakarta), 15 million rupiah aid/ household can be used to construct a dwelling house (individual families), but it is impossible to build a house with that amount of money in West Sumatra.

\section{Identification of Local Wisdom Value in Disaster Preparedness}

Local communities in this context, put on a very decisive position exceeds the government in handling natural disasters. Anthropologically, the community is not an independent entity; there is a set of values, morals, and institutions that affect the behavior of individuals in society. Knowledge and beliefs in the community is a set of concepts, values, category systems, methods, and theories used selectively to connect and interact with the surrounding. Thus the community-based disaster management is strongly influenced by perspective, culture, beliefs and the value of the local community.

Minangkabau traditional people have the understanding that nature and good geological systems in understanding the reality of nature are also the signs of nature. The order of nature is an absolute condition that cannot be contested. For them, nature provides instructions and directions how they 
should live and be able to defend themselves from disaster. This is reflected in the proverb:

\section{Panakiak pisau sirauik \\ Kagalah batang lintabuang \\ Salodang ambiak ka nyitu \\ Nan satitiak jadikan lauik \\ Sakapa jadikan gununang \\ Alam takambang jadi guru \\ (Hakimy, 1988: 2)}

According to Navis (1999), symbol of Alam Takambang Jadi Guru are the laws, regulations and also ethics governing people's lives. It makes human beings look like a natural substance that live as a single entity with each other. They do not compete each other to be the most important because they all have different roles. They are very smart in capturing the natural cues and responding appropriately to the cues. For the people of Minangkabau, following natural cues is also an effort to make friends with nature and reducing the risk of disaster that caused by nature.

In addition, local wisdoms of Minangkabau people which also teach about the layout and site selection, how to understand the soil structure and understand the structure of unstable earth is a step in the practice of the symbol. The anticipation of disaster based on traditional proverb is shown as follows:

Mancaliak tuah ka nan manang

sakali aia gadang

sakali tapian barubah

(Hamka, 1984)

The sentence above shows that the principle of Minangkabau people suggests them to take a lesson from past events that it will not recur in the future. This principle is used to reduce the damage when disaster happens, especially to reduce disaster caused by human and add an understanding of aspects that change the natural and contours of the earth.

In architecture and land management, Minangkabau people have the wisdom related to rumah gadang (the big house). Residential houses in Minangkabau are known as the big house. In addition to the main building, the complex is equipped with rangkiang (small house to store grain and other necessities), tabek (fish ponds) and a large courtyard. Rumah gadang or the big house is not only a physical matter, but more than that its functions and roles are related to social system that is built around the community (Navis, 1984).

Rumah gadang in West Sumatra is a symbol of local wisdom in facing floods, earthquakes, and tsunamis. The pattern of rumah gadang is vessel-shaped 
building with a curved roof ridge up approximately half circle. The sketch is essentially rectangular and the floors are on the top of the poles. Stairs to the house is in the middle (Hakimi, 2001). Rumah gadang is built with a height of about three meters from the ground with huge poles. Installation of the strong pillars and the floor at an altitude of three meters from the ground is useful to avoid disaster. Rumah gadang which does not have loft is also useful as a means of evacuation when floods or tsunami happens. In addition, other building and supporting elements like rangkiang, a pool and a large courtyard is a support tool for the community to cope with disasters.

In relation to social system, Minangkabau people also have local wisdom, known as Nagari (village), a social system which is the smallest administrative center in West Sumatra. Law number 34 in 2004 regulates regional government to give the place back to the village-level government unit for areas that have a traditional government. In West Sumatra the term Nagari is known as villagelevel customs administration. The head of Nagari is Wali Nagari (village leader). Institution and the supporting tools of Nagari are called as Kerapatan Adat Nagari (KAN) and led by KAN leader. KAN consists of representatives from ninik mamak, which are the heads of the board in the institution, and also bundo kanduang (mother). Besides, KAN consists of scholars and religious figure, as well as youths. Other institutions are BPRM (Board of Representatives of Nagari). In village-level customs administration, there is a unit called jorong headed by a trustee. The clan consists of a few families and leads by one Datuk (Ancestor). Inside the clans there are the officers named Malin (master) in charge. A clan has its communal land, cemetery, and Rumah Gadang (the big house) (Navis, 1984).

System of (nagari) village-level government is in charge of jorong, korong, and kampuang. At this level there are tribal kinship group which is a collection of communal blood family headed by a chief or an ancestor. Based on research conducted by Effendi (2007), this governance and management system is based on indigenous tribes in which a wali nagari (village leader) establishes policies and the programs should be based on the existing tribes (Hamka, 1984).

Minangkabau people are basically a very religious society which upholds the ethics of honesty, brotherhood, and togetherness. The system of government and the kinship system becomes social capital basis of the development of community, including in terms of dealing with disasters. Society plays a very dominant role to cope with disaster and to reduce victims because its basis of kinship is very strong.

el Harakah Jurnal Budaya Islam Vol. 19 No.1 Tahun 2017 


\section{Strengthening Local Wisdom Values through Local Community Based Disaster Management in Some West Sumatra Disaster Areas}

Disaster management is experiencing a shift of paradigm and act in accordance with Law number 25 in 2007, which focuses on community participation in disaster management. Society is not just becoming a victim/ object of the disaster but also as perpetrators of the disaster. According to Subiyantoro (2010), disaster management is basically not only the duty and responsibility of the government, but also the responsibility and obligation of people which can be conducted by anticipating the disaster through the power of the community, namely community based empowerment resting on the ability of local resources (community-based disaster management).

Community-based disaster management has been done by some non-governmental organizations such as; IDEP (2007) with a PBBM model (Community Based Disaster Management), Bakornas BP (2007) with a model CBDRM (community-based disaster risk management), Ministry of Social Affairs with ICBRR-CC (Integrated community Base Risk Reduction Climate Change, and the model which is being developed by Indonesian Red Cross called Community-based Disaster Preparedness (Thoyib, 2010). Principally the model being developed by this institution is a community-based program that encourages the empowerment of communities' capacity to alert them to prevent and mitigate the effects and risks of disasters.

However, according to Abdullah (2006), there are some social response in the implementation of community-based disaster management program; first, modern society relies on science and technology in facing and handling disasters and its potential. In other words, modern society uses technocracy and seems to disregard human's central position. Second, local communities face disaster without using science and technology. Therefore, they cannot predict natural disasters scientifically because they assume that natural events occur because of God's will.

Therefore, to prevent massive losses due to management irregularities and unpreparedness of populations caused by disaster, efforts to build community resilience to disasters by optimizing the value of culture and local wisdom is certainly needed. This is done so that society and all stakeholders, including government, private sector and non-governmental organizations can conduct integrated disaster management, and not just follow the models that are not necessarily suited to local conditions, but also prioritize forms of practice of local wisdom, although these values are increasingly eroded by the times. 
Furthermore, this paper will analyze some form of local knowledge that is being applied by communities in several disaster areas in West Sumatra.

\section{Badoncek Tradition: A local Wisdom of Peoples in Nagari Tandikat Padang Pariaman}

Nagari Tandikat is one of the districts that have been affected severely by the earthquake on September, 30, 2009. Almost 90\% of the buildings were severely damaged, 260 people died, 79 people were missing and one village was missing due to the landslides. Uniquely, Nagari Tandikek which has some Korong; Jumanak, Gunuang Tigo, Lubuak Laweh located in Patamuan District, Padang Pariaman, after the initial earthquake in West Sumatra suddenly becomes famous because many people come to see the lost village (Detikcom, 2009).

Jorong Gunuang Tigo is the name of the lost village in Tandikat. Hundreds of people are buried by the hills surrounding the village. This occurs because the soil structure of Tandikat is the alluvial soil types; soil of volcanic ash that is highly overtime and easily fall or landslides when the earthquake struck. So no wonder, if then, Nagari Tandikek really looks like a "dead villages". Because of the severity of the evacuation of casualties in the area of this landslide, on the fifth day after the earthquake, the searching process was being stopped. With some considerations and agreement of parties in West Sumatra, Provincial Government finally agrees that Gunuang Tigo, Tandikek village, Patamuan District, Padang Pariaman becomes a mass grave (Tabloidnova.com, 2009).

In addition to the number of dead and missing people from the earthquake, there are still about 300 people survivors in Koto Island and Lubuk Laweh Village with very poor housing conditions (Rahman, 2013). At the time of evacuation process, some teams of disaster response such as content rated community groups and PKPU rescue survivors and reconstruct it.

There are local values that are being developed by villagers of Tandikat in dealing with natural disasters which is the tradition of badoncek. It is social culture used by Minang people in the past in the form of mutual contribution of material to sustain public activities or in the form of spontaneity help for village children to meet individual needs afflicted.

One of the volunteers of PKPU, Anton, declared that badoncek tradition is the appropriate media which is agreed by the victims because it is suitable with the tradition and it has been applied once before. The excerpts of the interview are provided below:

el Harakah Jurnal Budaya Islam Vol. 19 No.1 Tahun 2017 
"All elements of volunteers, local communities and citizens of Tandikat were
preoccupied with setting assistance coming from several directions. In the
field, we had to argue with the distribution mechanism directly on the victim.
Only unexpectedly citizens and survivors of Tandikat are readily within their
communities. Each citizen voluntarily donates to ease the burden among them
according to their capabilities without coercion. Some brought rice, side dishes
or anything left in their homes and taken to temporary shelters. From the
talk to residents that is known by badoncek tradition. With the strength of this
community readiness we predict there among refugee communities should not
always wait for and expect help from the outside because of their readiness ".
Badoncek activities undertaken by Tandikat community is a tradition of social mobilization, in which they affirmed that their tradition of collective action came directly from the bottom to overcome their social problems including natural disasters, landslides, and earthquakes today. Amran, the leader of Tandikat, stated that the procedure of badoncek tradition is usually coordinated spontaneously by one of the community leaders as explained in the following excerpts of interview:

"Technically, badoncek is a spontaneous social action and suitable with the needs of the moment. Community is spontaneously involved in the action initiated by local leaders with certain propaganda such as the need to help victims of landslides for example. On behalf of the public interest, public figures have started to socialize through the medium to gather citizens, mosques and others. Currently there is the originator of the tradition bandoncek using social media such as Facebook, tweeter and mailing. Due to unplanned and spontaneity, the accumulated financial tend to be unwell-organized. But at least, this tradition has built public awareness of the issues in society that occurred."

Badoncek tradition is still maintained by the community of Tandikat, Padang Pariaman these days. Badoncek is not only used to alleviate the burden when disaster happens, but it is also applied in a stable condition such as when community build public facilities including roads, mosques and other public facilities. In fact, this tradition is also used when one of the residents hold weddings and any other events. Badoncek culture at its core has a deep meaning in the traditional Minangkabau philosophy. The essence of life shows that human beings do not live on their own, but they need to help each other and they should lend a hand to help social interest (Navis, 1984). Besides, badoncek not only socially sustains public activities, but it is more oriented to counter countries limitations in overcoming the public affairs, especially from the financial side. This Local wisdom has several advantages toward society's independence and the participation of the public, especially one of the utilization of local values in the implementation and application 
of community-based disaster management that are being developed in some disaster-prone areas in Indonesia.

\section{Spatial and Architecture of Rumah Gadang: Architectural Design as a Local Wisdom of Nagari Sungayang, Tanah Datar}

Nagari Sungayang is one of the villages in Tanah Datar district where traditional settlement pattern is still visible from where rumah gadang (the big house) with original architecture is quite a lot. Nagari Sungayang with area \pm 8 $\mathrm{km}$ divided into five sub-villages namely: Taratak Indah, Galanggang Tangah, Balai Gadang, Balai Diateh and Sianok Indah. Rumah gadang with the original architecture can still be found in every sub-village.

Sungayang is in the highlands with an altitude ranging from $600-750 \mathrm{~m}$ above sea level. This region has a hilly topography flanked by Mount Merapi and Mount Sago. Traditional villages are scattered on the backs of the slopes of Mount Merapi where a water source and a place of worship located in the lower area of the township area. Rumah gadang Sungayang is built in line with the longitudinal direction of the ridge following the slopes of Mount Merapi, so we can see the regular pattern of the layout of Rumah gadang in a group of villages (the Goddess, 2010). Some types of Rumah gadang located in Nagari Sungayang are generally found in several areas of Minangkabau. The types are explained below:

1. Gajah Maharam. The model of Gajah Maharam building with four pointed roof (Gonjong) is considered to be the original form of Minangkabau traditional House. The building can be found in Pariangan, Padang Panjang, Tanah Datar Regency and any other areas. Features of this building are the termination on the left and right side of the building, straight, and do not end with stage (anjuang).

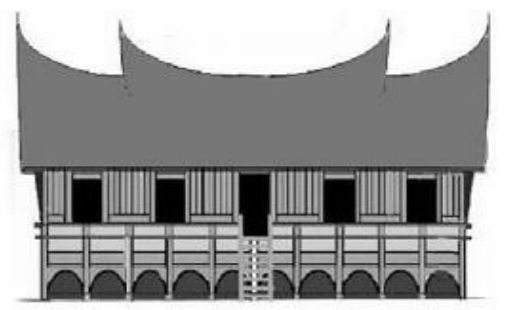

Figure 1. Rumah Gadang Gajah Maharam (Source: Couto, 1998)

el Harakah Jurnal Budaya Islam Vol. 19 No.1 Tahun 2017 
2. Gonjong Ampek Sibak Baju. Gonjong Ampek Sibak Baju RA of Koto's clan, in Tampang, Sungayang village consists of five rooms. Notice the two gonjong in the middle of the house, termination on the two gonjong of the central part is in the form of a line (declining path). Its basic form is essentially Gajah Maharam building.

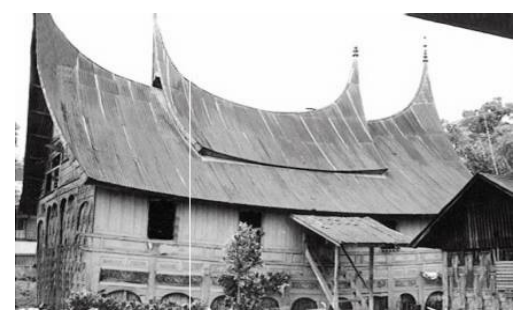

Figure 2. Rumah Gadang Gonjong Ampek Sibak Baju

(Source: Couto, 1998)

3. Surambi Aceh Bagonjong Ciek jo Duo is emerging from the needs of guests who are not recipients of Minang (colonial) and not allowed (taboo) to enter the traditional house/ Rumah Gadang. Building of Istano Rajo Balun has a front porch with two gonjong which are parallel to the building.

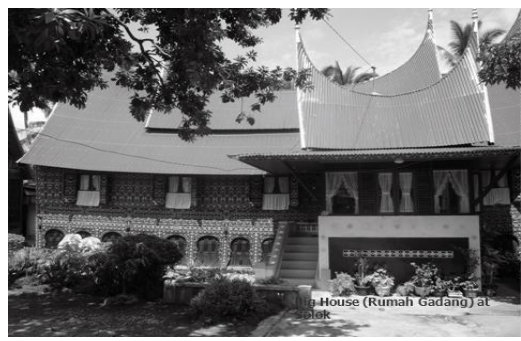

Figure 3. Rumah Gadang Surambi Aceh Bagonjong Ciek jo Duo

(Source: Couto, 1998)

Architectural system in Sungayang has several key elements that make the structure of the building which is $100 \%$ derived from nature is proven and tested to be able to resist earthquake shaking. The following is statement of Mak Katik, a traditional figure in Nagari Sungayang:

"When it started to build the house, the three key elements of Rumah Gadang which make it safe from earthquakes should be remembered. First, Rumah Gadang is using proprietary systems, not deadly nailed. This makes the structure sway elastically following the movement, when the earthquake occurred, so it will not be apart. Second, at the bottom, the pole of the big house is not directly connected to the ground. At the bottom of the pole there is a stone, which will dampen the vibrations from the ground during earthquakes. Third, at the top, the roof of Rumah Gadang made of light fibers. Fiber material reduces the 
heavy burden on the building. Now, many of them are replaced by zinc, which also relatively light, but there is not Rumah Gadang with heavy tile-roofed."

Some experience of earthquake happened in West Sumatra gives a lot of valuable lessons about disaster preparedness. In Sungayang village, an area which is close to the epicenter of Tanah Datar earthquake in 2007, Rumah Gadang as the representation of local wisdom is still standing strong despite the onset of earthquake (Erwin, 2011). Deaths and injuries are mostly caused by the collapse of buildings. It was like a sign that local wisdom taught by Minangkabau ancestors for hundreds of years in building the house no longer exists in people's daily habits. In fact, Rumah Gadang is a synthesis of how the Minangkabau people answer the question. The structure and shape of Rumah Gadang is the intention, culture and thoughts that proceed in a long time.

Traditional house is categorized as non-engineered residential construction transferred from generation to generation of ancestors, and it would be able to withstand the environment (earthquakes, climate, floods, etc.) and easily accepted by the local community. The method and system of traditional houses is part of the development of local wisdom for the population of an area. The development of local knowledge about the material, employee skills and techniques that are used on a building during the last century reflects the human desire to meet the housing needs and also the need of society in facing natural behavior like disasters. Traditional houses are usually built to bring together a variety of interests, values, and way of life of local communities (Abdullah, 2012).

\section{Traditional Community-based Disaster Mitigation in Kubang Putih Agam}

According to the Regulation of the Minister of Internal Affair number 33 in 2006, mitigation is defined as an effort aimed at reducing the impact of disasters, both natural disasters and human made disasters or a combination of both in a country or community. Mitigation of earthquake disaster is an action taken to mitigate the impact in the event of an earthquake, both mitigation of structural and non-structural mitigation (Pribadi, 2008).

According to Pribadi (2008) structural mitigation is a series of actions taken through physical development to reduce the impact caused by the earthquake like an attempt to construct a building that is friendly to earthquake shaking. Non-structural mitigation is a series of non-physical action that is done to reduce the impact caused by the earthquake.

el Harakah Jurnal Budaya Islam Vol. 19 No.1 Tahun 2017 
The purpose of earthquake disaster mitigation is to develop mitigation strategies to reduce the loss of human life and the natural surroundings and property, human suffering, the economic damage and costs required to handle disaster victims generated by the earthquake hazard.

A mitigation and disaster management system by utilizing the potential and the institutional values of local wisdom is being applied in Nagari Kubang Putiah Agam. Nagari Kubang Putiah at the foot of Mount Merapi is one of the villages in the Mount Merapi which is predicted to be affected by the eruption of Mount Merapi; one of the active volcano that is experiencing the causes and effects of the earthquake in West Sumatra. Administratively, the village consists of 7 sub-villages in Banuhampu Agam District. These villages are within a radius of 3-4 km from the center of the crater of Mount Merapi.

As one of the villages of West Sumatra that implements the village-level government system, Nagari Kubang Putiah made up of several clans, led by the ancestor. A clan has communal land, cemetery and Rumah gadang. An ancestor assisted by officers called malin and dubalang are in charge of maintaining social relationships and customary maintenance occurs on the scope of clan and villages. Systems and traditional social relations is being strengthened and nurtured by the people of Kubang Putiah through the village disaster preparedness program. Here is the transcript of an interview with the leader of Kubang Putiah Village:

"This traditional kinship system will be built continuously so that a family group or tribe in Kubang Putiah will do everything possible to prioritize action to help the family of the unfortunate. They will be embarrassed if there is a close family in difficulties. So that at the time of the earthquake happened, refugee camps just for a while, they help their relatives to accommodate the victims in the home of the family "rumah pusako". The value system of "rumah pusako" is that a large family home allows the whole family to have and contribute to build the house.

Beside to strengthening social relations, Kubang Putiah people through the disaster response and readiness program lead by Paga Nagari are actively reforming the structure and institutional form such as disaster response and preparedness teams in the level of villages and the sub-villages, training and workshops to socialize the group-based disaster response, the preparation of evacuation paths and prepare facilities and infrastructure good road to the evacuation route when the earthquake and the eruption of Mount Merapi was really happening. 
Village based disaster mitigation and management is an effort to harness the potential of local wisdom in Minangkabau society which is institutionally and structurally very strong. Strict kinship system from the clan level with emotional and descent attachment at least facilitate disaster response management. Furthermore, at the level of village consisting of some sub-villages, a traditional structural institution can be maximized as neat and structured disaster management coordination lines. This experience is making it easier for governments and donors to deliver aid to villages in West Sumatra which become disaster victims. At the level of the sub-villages with a highly emotional strength, valid data of casualties and material losses will be easily obtained.

\section{Conclusion}

Local wisdom value is knowledge in the form of local or indigenous knowledge; a knowledge of indigenous people who live in certain geographic locations, which have a culture and belief system that differ from the modern intellectual world knowledge. It is a set of knowledge that was created by a group of people through generations living together and in harmony with nature.

Badoncek tradition, the architecture of Rumah Gadang and village-based disaster mitigation is part of many traditional values of indigenous peoples of Minangkabau in addressing disaster management efforts. This local wisdom is growing in the local scope, adjusting to the circumstances and needs of the community. This knowledge is the result of creativity and innovation followed by the involvement of internal input and external influences in an effort to adjust to the new conditions of local.

Thus, the indigenous knowledge or local wisdom as a collective experience accumulated from generation to generation need to be developed as the part of the enriching and completing the assembly of technological innovation of sustainable future, including disaster management.

Excavation of local wisdom in disaster management has been carried out by researchers from different institutions and organizations both in Indonesia and outside Indonesia. Some local wisdom in anticipating and addressing the impact of natural disasters has the potential to be developed by the local indigenous community after the development in the revitalization and adaptation to fit the local culture and environment conditions.

el Harakah Jurnal Budaya Islam Vol. 19 No.1 Tahun 2017 


\section{References}

Abdullah, Irwan. 2006. Dialektika Natur, Kultur dan Struktur: Analisis Konteks, Proses dan Ranah dalam Konstruksi Bencana. Pidato Pengukuhan Guru Besar Antropologi UGM Yogyakarta.

Abdullah, Maulana. 2012. Pola Ruang dalam Bangunan Rumah Gadang di Kawasan Alam Surambi Sungai Pagu Sumatera Barat. Jurnal Arsitektur UGM 3(1), 97-106.

Couto, Nasbahry. 1998. Makna dan Unsur-Unsur Visual pada Bangunan Rumah Gadang. Tesis Pasca Sarjana tidak diterbitkan. Bandung: Jurusan Seni Murni, Fakultas Seni Rupa dan Desain ITB.

Danhas, Mardayeli. 2011. Efektivitas Pelaksanaan Kebijakan Penanggulangan Bencana di Provinsi Sumatera Barat. Tesis Program Pasca Sarjana Universitas Andalas Padang.

Effendi, Nusyirwan. 2007. Bencana; Pengalaman dan Nilai Budaya Orang Minangkabau. Jurnal Masyarakat Indonesia LIPI 2(2), 200-210.

Hakimy, Idrus Dt Rajo Panghulu, 1988. Pegangan Penghulu, Bundo Kanduang, dan Pidato Alua Pasambahan Adat di Minangkabua. Bandung: Remadja Karya.

Hakimy, Idrus Dt Rajo Panghulu. 2001. Rangkaian Adat dan Mustika Adat dan Syara' Minang Kabau. Bandung: Rosyda Karya.

Hamka. 1984. Islam dan Adat Minangkabau. Jakarta: PT Pustaka Panjimas.

Ismail, Febian Anas. 2007. Damage Houses in West Sumatera Due to March 6,2007 Earthquake Case Study; The City of Padang Panjang. Workshop on Risk Modelling and Vulnerability Assessment. Bandung: LIPI, DRL dan UNU Jerman.

Lengga, Pradipta. 2015. Membangun Ketangguhan Masyarakat Terhadap Bencana Alam Melalui Praktik Kearifan Lokal di Sumatera Barat. Konferensi Kebencanaan Pusat Kependudukan. Yogyakarta, 26-28 May.

Navis, A.A. 1984. Alam Takambang Jadi Guru. Jakarta: PT Grafiti.

Pribadi, Krishna S. 2008. Buku Pegangan Guru: Pendidikan Mitigasi Bencana. Bandung: Pusat Mitigasi Bencana ITB. 
Rahman, Septia. 2013. Tingkat Pemahaman Masyarakat Nagari Tandikat Kecamatan Patamuan Kabupaten Padang Pariaman Tentang Mitigasi Bencana Gempa Bumi. Cived Unp.1(2), 184-189.

Sunarti, Euis [Ed]. 2009. Evaluasi Penanggulangan Bencana di Indonesia (Lesson Learned 2006-2007). Bandung: Pusat Studi Bencana LP2M IPB.

Suryati. 2013. Gambaran Kebutuhan dan Perilaku Remaja Putri pada waktu Menstruasi dalam Situasi Darurat Bencana di Sumatera Barat. Jurnal Kesehatan Masyarakat 7(2), 54-59.

Thoyib, M. 2010. Manajemen Bencana Berbasis Masyarakat, diakses dari www. depsos.go.id/modules.php.

Tim BPPT. 2010. Laporan Rapid Assessment: Bencana Gempa Bumi dan Bencana Kolateral Longsor dan Kebakaran di Sumatera Barat 30 September 2009. Pusat Teknologi Sumberdaya Lahan Wilayah dan Mitigasi Bencana Kedeputian Teknologi Pengembangan Sumberdaya Alam Badan Pengkajian dan Penerapan Teknologi.

Tim IDEP. 2007. Panduan Umum Penanggulangan Bencana Berbasis Masyarakat. Bali: Yayasan IDEP.

Tim Penyusun. 2006. Hasil Simposium Nasional Kedua Manajemen Resiko Bencana Berbasis Masyarakat Mencari Jadi Diri Bangsa Indonesia. Jakarta: Tim Bakornas BP. 12-13 April.

Tim Penyusun . 2007. Panduan Pengenalan Karakteristik Bencana dan Upaya Mitigasinya di Indonesia. Jakarta: Tim Bakornas BP. 
